\title{
The role of mechano-growth factor $E$ peptide in the regulation of osteosarcoma
}

\author{
JIN SHANG ${ }^{*}$, XIN FAN ${ }^{*}$ and HUAN LIU \\ Department of Orthopedics, Xinqiao Hospital, Third Military Medical University, Chongqing 400037, P.R. China
}

Received August 26, 2014; Accepted May 7, 2015

DOI: $10.3892 / 01.2015 .3339$

\begin{abstract}
Osteosarcoma is one of the most common bone tumors, and exhibits a high degree of malignancy. Gene therapy is a novel approach to its treatment, however, specific target genes are required to enable effective use of this therapy. In order to investigate the effects of the mechano-growth factor $\mathrm{E}$ (MGF-E) peptide, which is derived from the IGF-I alternative splicing isoform, on the regulation of the development of osteosarcoma, the expression of MGF was detected in osteosarcoma cell lines with different degrees of malignancy. Concomitantly, exogenous MGF-E peptide was used to stimulate these osteosarcoma cell lines. The results demonstrated that MGF was overexpressed in malignant osteosarcoma cells, while it was not expressed in the least malignant osteosarcoma cells. Furthermore, MGF-E treatment altered the cell cycle distribution, and promoted the proliferation, migration and invasion of osteosarcoma cells. The possible mechanisms underlying these effects were detected by quantitative polymerase chain reaction and western blotting. Based on these results, it was hypothesized that MGF may be a suitable biomarker for malignant osteosarcoma phenotypes.
\end{abstract}

\section{Introduction}

Osteosarcoma is the most common malignant bone tumor, accounting for $20 \%$ of all bone tumors $(1,2)$. Current therapy involves surgical removal of the malignant lesion, in association with chemotherapy. Survival rates of $60-80 \%$ are obtainable for cases of osteosarcoma without metastasis (3). In recent years, there have been advances in gene therapy for osteosarcoma, including immune gene therapy, antisense gene therapy and suicide gene therapy (4-6). Cancer gene

Correspondence to: Dr Huan Liu, Department of Orthopedics, Xinqiao Hospital, Third Military Medical University, 183 Xinqiao Main Street, Chongqing 400037, P.R. China

E-mail: 20016040@163.com

${ }^{*}$ Contributed equally

Key words: mechano-growth factor E, osteosarcoma, proliferation, migration, invasiveness therapy is a novel treatment approach, and it is a revolution in cancer treatment. Studies have focused on the involvement of certain growth factors, which may affect the development of osteosarcoma. These factors may be of use in the development of novel medications for the treatment of this disease.

The insulin-like growth factor I (IGF-I) gene generates three mRNA isoforms during transcription, including IGF-I Ea, IGF-I Eb and IGF-I Ec. IGF-I Eb in rodents, and IGF-I Ec in humans, are also termed mechano-growth factor (MGF) (7-9). MGF has been widely studied in biological and medical fields. It is established as a stimulator of myoblast and osteoblast proliferation, and protects neuronal and cardiomyocyte apoptosis, inhibits osteoblast differentiation and mineralization, and stimulates mesenchymal stem cell proliferation and migration (10-13). Furthermore, MGF expression has been demonstrated to be associated with different diseases, including those affecting tissue repair and regeneration, and cancer (14). Compared with healthy tissues, MGF has been indicated to be overexpressed in neuroblastoma, prostate cancer and osteosarcoma (15-17).

There is a unique E domain in the C-terminal of MGF that distinguishes MGF from other IGF-I isoforms in terms of its peptide sequence and function $(12,18,19)$. The present study aimed to measure the expression of MGF mRNA in Hos, MHos and MG-63 cells, and to investigate the actions of the MGF-E peptide in human MG-63 cells in vitro. It has previously been demonstrated that cyclinD1 is required for G1/S transition in cell proliferation (20), caspase-3 is essential for apoptosis (21), and VEGF is the best characterized regulator of angiogenesis (22). High expression levels of CD147 and MMP-9 are positively correlated with invasion and metastasis of various cancers, such as triple-negative breast cancer and laryngeal carcinoma $(23,24)$. The expression levels of these proteins in MG-63 cell after MGF-E treatment are detected. The results indicated that exogenous MGF-E peptide is involved in the regulation of cell cycle distribution, in addition to the proliferation, migration and invasion of MG-63 cells. This indicates that MGF may be a suitable biomarker gene of malignant osteosarcoma.

\section{Materials and methods}

Cell lines and culture. The human osteosarcoma cell lines Hos, MHos and MG-63 were purchased from CCTCC (Shanghai, China) and all cultured in MEM medium (GE Healthcare 
Life Sciences, Logan, UT, USA) with $10 \%$ fetal bovine serum (FBS, Merck Millipore, USA) and 1\% Penicillin-Streptomycin (Solarbio, Beijing, China). Cells were incubated at $37^{\circ} \mathrm{C}$ in $5 \% \mathrm{CO}_{2}$. For cell seeding, the cells were washed with phosphate-buffered saline (PBS) and digested with $0.25 \%$ Trypsin-EDTA (Solarbio, Beijing, China). The MHos and MG-63 cell lines are more malignant than Hos (25).

Cell counting kit-8 (CCK-8) assay for measurement of $M G$-63 cell proliferation. The study was approved by the ethics committee of Department of Orthopedics, Xinqiao Hospital (Chongqing, China). MG-63 human osteosarcoma cell proliferation activity was assessed by direct cell counting subsequent to cell seeding. Briefly, MG-63 cells were cultured at a density of $2 \times 10^{3}$ cells/well in 96-well plates $(200 \mu \mathrm{l} /$ well $)$ and incubated at $37^{\circ} \mathrm{C}$ for $24 \mathrm{~h}$. Cells were then exposed to conditioned medium (containing 0, 10, 20, 50 or $100 \mathrm{ng} / \mathrm{ml}$ MGF-E; Catalog no. 033-42; Phoenix Pharmaceuticals, Burlingame, CA, USA) for 0,24 or $48 \mathrm{~h}$. Cell proliferation was evaluated using the CCK- 8 assay (Beyotime Institute of Biotechnology, Haimen, China) according to the manufacturer's instructions. CCK-8 solution $(20 \mu \mathrm{l})$ was added to each well of the 96 -well plate. Following incubation at $37^{\circ} \mathrm{C}$ for $2 \mathrm{~h}$, the plates were analyzed using an ELISA reader at $450 \mathrm{~nm}$. Data are presented as the mean \pm standard deviation from 5 independent experiments.

Cell cycle assay. Conditioned cultured MG-63 cells were washed with phosphate-buffered saline (PBS) and digested with $0.25 \%$ Trypsin-EDTA solution (Solarbio). Test cells were immobilized with $75 \%$ alcohol and stained with propidium iodide (PI; Sigma-Aldrich Chemie GmbH, Munich, Germany). A FACSCalibur Flow Cytometry System (BD Biosciences, Franklin Lakes, NJ, USA) was used for single-cell analysis.

Scarification test. MG-63 cells were seeded in 6-well plates at a density of $2 \times 10^{5}$ cells/well. Following culture for $24 \mathrm{~h}$, wounds were created in the cell monolayer using a pipette tip. Dead cells were removed using 0.1 mM PBS. Cells were treated with MGF-E peptide at various concentrations $(0,10$, 20,50 and $100 \mathrm{ng} / \mathrm{ml}$ ) and all the groups were treated with serum-free medium for $24 \mathrm{~h}$. Images were captured at 0 and $24 \mathrm{~h}$. The migration distance was using Photoshop version 3.0 (Abode Systems, Inc., San Jose, CA, USA).

Transwell chamber assay. MG-63 cells were seeded at a density of $2 \times 10^{5}$ cells/well into the top chamber of Transwell-COL co-culture systems $(8.0 \mu \mathrm{m}$ pore size; Costar, Corning, Shanghai, China) were starved in serum-free minimum essential medium (MEM) for $24 \mathrm{~h}$. Cells were then treated with MGF-E peptide at various concentrations $(0,10,20,50$ and $100 \mathrm{ng} / \mathrm{ml}$ ) in $200 \mu \mathrm{l}$ serum-free MEM (GE Healthcare Life Sciences). MEM (500 $\mu \mathrm{l})$ containing 20\% FBS was added to the bottom chamber. The Transwell plates were incubated at $37^{\circ} \mathrm{C}$ for $24 \mathrm{~h}$. The upper chamber was removed, and cells on the upper chamber surface of the basement membrane were removed using cotton swabs. Cells that had invaded the lower chamber surface of the basement membrane were stained with crystal violet (Solarbio). The number of migrated cells in the bottom chamber was quantified using an Inverse Fluorescent IX73 Microscope with a micropublisher 5.0 RTV (Olympus Corporation, Tokyo, Japan).

RNA isolation. Total RNA was isolated from the conditioned cultured cells using a High Pure Viral RNA kit (Bioteke Corporation, Beijing, China). The integrity of RNA was determined by electrophoresis at $100 \mathrm{~V}$ on a $1.5 \%$ agarose gel (Beyotime Institute of Biotechnology, Beijing, China) with Goldview (Solarbio). RNA quality and quantity were determined using a NanoDrop 2000 spectrophotometer (Thermo Fisher Scientific, Waltham, MA, USA).

Quantitative polymerase chain reaction $(q P C R)$. Total RNA was isolated from the conditioned cultured Hos, MHos and MG-63 cells. Then the RNAs were transcribed to cDNAs use the PrimeScript RT reagent Kit with gDNA Eraser (Cat\#RR047A, Takara Biotechnology Co., Ltd., Dalian, China)). The expressions of genes associated with proliferation, migration and invasion were measured by qPCR with a StepOne Plus thermocycler (Bio-Rad Laboratories, Hercules, CA, USA). A cDNA template (2 $\mu 1)$ and $12.5 \mu 12 \mathrm{X}$ SYBR Premix ExTaq II (Takara Biotechnology Co., Ltd.) were added, to obtain a final volume of $25 \mu 1$. The thermal cycles were performed at $95^{\circ} \mathrm{C}$ for $30 \mathrm{sec}, 40$ cycles at $95^{\circ} \mathrm{C}$ for $5 \mathrm{sec}$, and $60^{\circ} \mathrm{C}$ for $30 \mathrm{sec}$. The primer sequences were as follows: MGF, F 5'-GCCCCCATCTACCAACA AGAACAC-3' and R 5'-CGGTGGCATGTCACTCTTCACTC-3'; GADPH, F 5'-CCTCCTGCACCACCAACTGCTT-3' and R 5'-GAGGGGCCATCCACAGTCTTCT-3'. Sequences of differentially expressed genes were obtained from GenBank (http://www.ncbi.nlm.nih.gov/Genbank/index. html). Primers were designed by Primer 3.0 (http://frodo. wi.mit.edu).

Western blotting. Cells were lysed in radioimmunoprecipitation buffer (Beyotime Institute of Biotechnology) with protein inhibitor, phenylmethylsulfonyl fluoride (CWBIO, Beijing, China), to obtain a final concentration of $1 \mathrm{mM}$. Samples were maintained on ice for $30 \mathrm{~min}$, then centrifuged at $14,000 \times \mathrm{g}$ for $3-5 \mathrm{~min}$ at $4^{\circ} \mathrm{C}$, and the supernatant was collected. The concentrations of cyclin D1, CD147, matrix metalloproteinase 9 (MMP-9) and vascular endothelial growth factor (VEGF) were detected using an Enhanced BCA Assay kit (Beyotime Institute of Biotechnology) according to the manufacturer's instructions. Proteins were resolved by SDS-PAGE in a 10\% polyacrylamide gel and transferred to polyvinylidene difluoride membranes (EMD Millipore, Billerica, MA, USA). Membranes were blocked in Tris-buffered saline with $0.1 \%$ Tween- 20 and $5 \%$ non-fat milk (Solarbio) for $1 \mathrm{~h}$ at room temperature. The membranes were immunoblotted with mouse monoclonal anti-human MMP-9 (2C3) (Cat No. sc-21733), mouse monoclonal anti-human EMMPRIN (F-5) (Cat. No. sc-374101), mouse monoclonal anti-human cyclin D1 (HD11) (Cat. No. sc-246), mouse monoclonal anti-human VEGF (JH121) (Cat. No. sc-57496), mouse monoclonal anti-human caspase-3 (31A1067) (Cat. No. sc-56053), mouse monoclonal anti-human Actin (C-2) (Cat No. sc-8432) (1:1,000; Santa Cruz Biotechnology, 
A

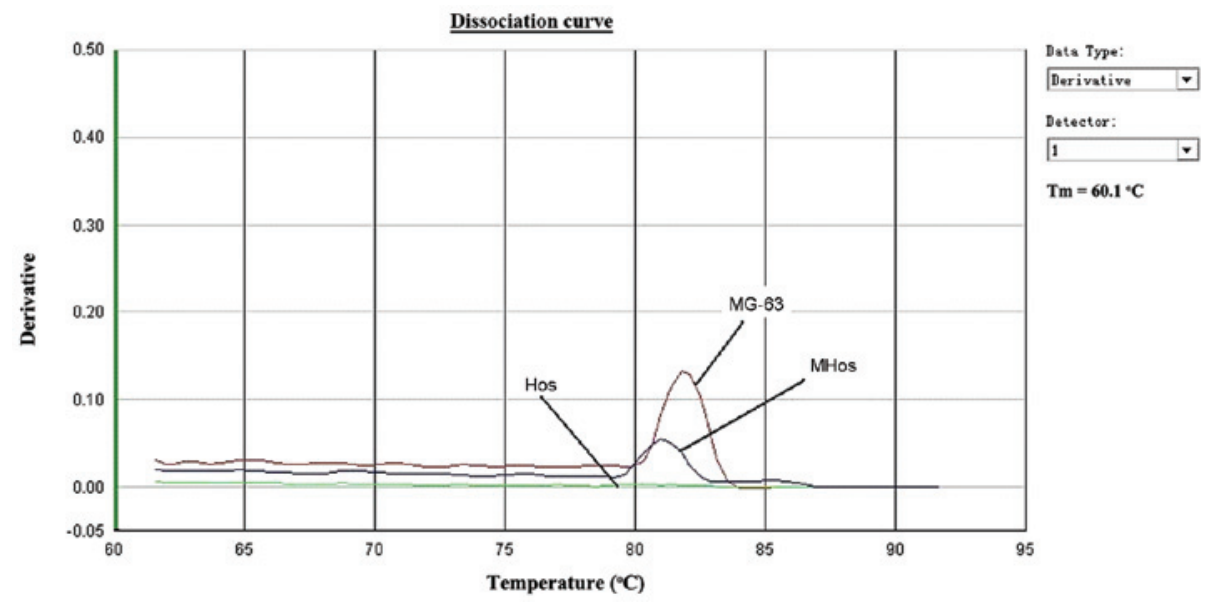

B

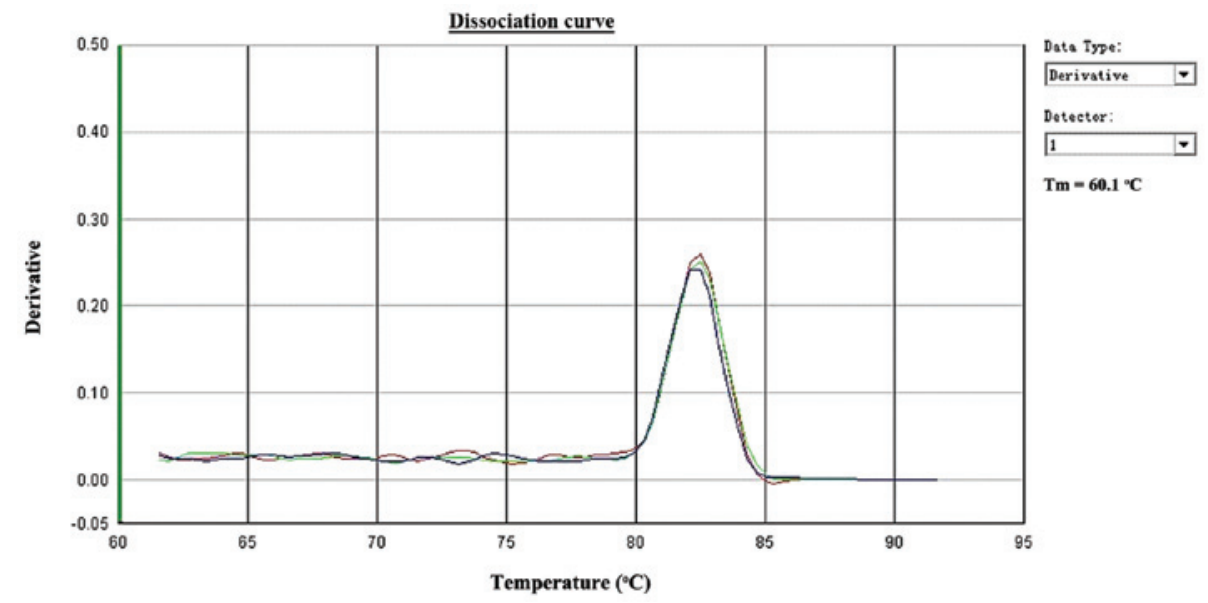

Figure 1. Quantitative analysis of (A) MGF and (B) GAPDH mRNA in Hos, MHos and MG-63 osteosarcoma cell lines using quantitative polymerase chain reaction. MHos cells and MG-63 cells expressed MGF, while Hos cells did not. Normalization in all cases was conducted using GAPDH. MGF, mechano-growth factor.

A

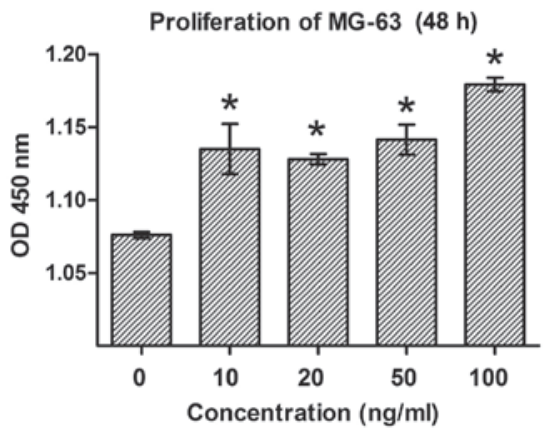

B

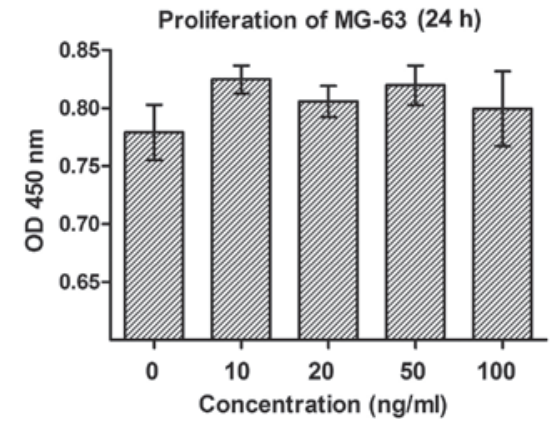

Figure 2. Proliferation of MG-63 cells in response to treatment with MGF-E peptide treatment at various concentrations $(0,10,20,50$ and $100 \mathrm{ng} / \mathrm{ml})$ for (A) 48 and (B) $24 \mathrm{~h}$. Data are presented as the mean \pm standard error $(\mathrm{n}=5$ per concentration). ${ }^{*} \mathrm{P}<0.05$, vs. $0 \mathrm{ng} / \mathrm{ml}$. MGF-E, mechano-growth factor $\mathrm{E}$; OD, optical density.

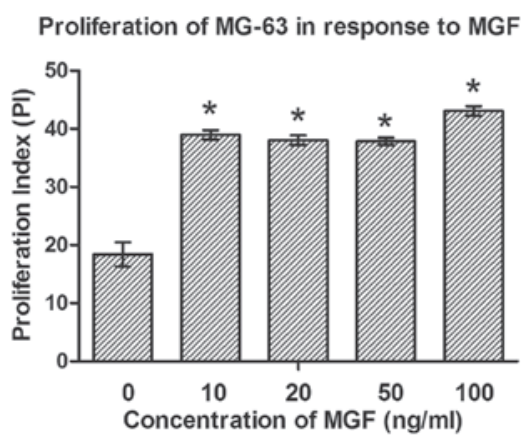

Figure 3. Effects of MGF-E peptide on MG-63 cell cycle progression were analyzed. MG-63 cells were treated with MGF-E peptide at various concentrations $(0,10,20,50$ and $100 \mathrm{ng} / \mathrm{ml})$. Data are presented as the mean \pm standard error $\left(\mathrm{n}=5\right.$ per concentration). ${ }^{*} \mathrm{P}<0.05$ vs. control. MGF-E, mechano-growth factor $\mathrm{E}$.

Inc., Dallas, TX, USA) overnight at $4^{\circ} \mathrm{C}$, and HRP-labeled Goat Anti-Mouse IgG (H+L)(Cat No.AB503-01A, Beijing Zhongshan Golden Bridge Biotechnology Co., Ltd., Beijing, China)for $2 \mathrm{~h}$ at RT. Immunoreactive proteins were visualized using BeyoECL Plus chemiluminescent detection (Beyotime Institute of Biotechnology) and the band intensity relative to actin was acquired using Quantity One software version 4.2 (Bio-Rad Laboratories, Inc., Hercules, CA, USA). 
A

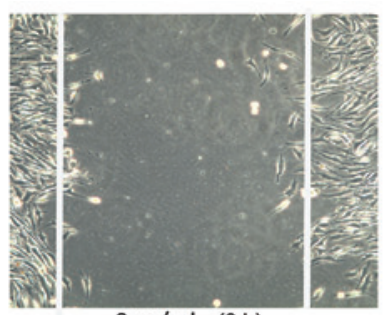

$0 \mathrm{ng} / \mathrm{ml}(0 \mathrm{~h})$

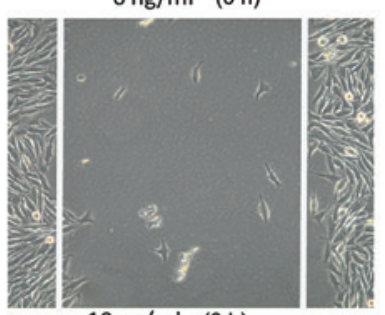

$10 \mathrm{ng} / \mathrm{ml} \quad(0 \mathrm{~h})$

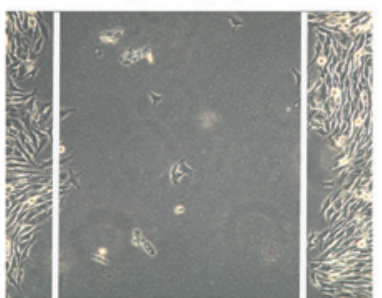

$20 \mathrm{ng} / \mathrm{ml}(0 \mathrm{~h})$

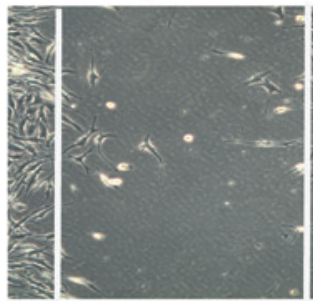

$50 \mathrm{ng} / \mathrm{ml}(0 \mathrm{~h})$

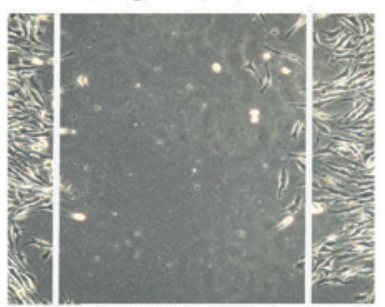

$100 \mathrm{ng} / \mathrm{ml}(0 \mathrm{~h})$

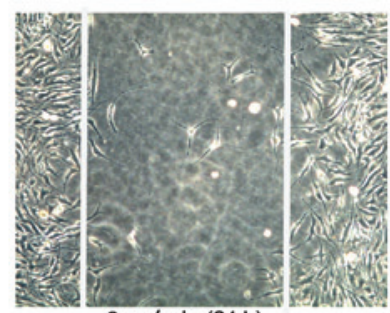

$0 \mathrm{ng} / \mathrm{ml} \quad(24 \mathrm{~h})$
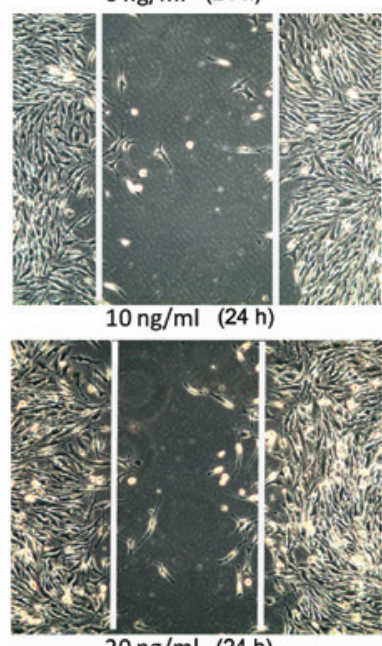

$20 \mathrm{ng} / \mathrm{ml}(24 \mathrm{~h})$

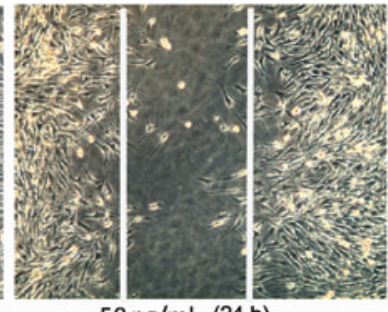

$50 \mathrm{ng} / \mathrm{ml}(24 \mathrm{~h})$

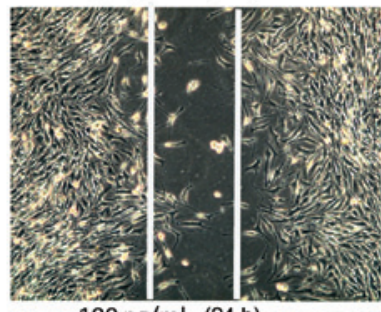

$100 \mathrm{ng} / \mathrm{ml}(24 \mathrm{~h})$
B

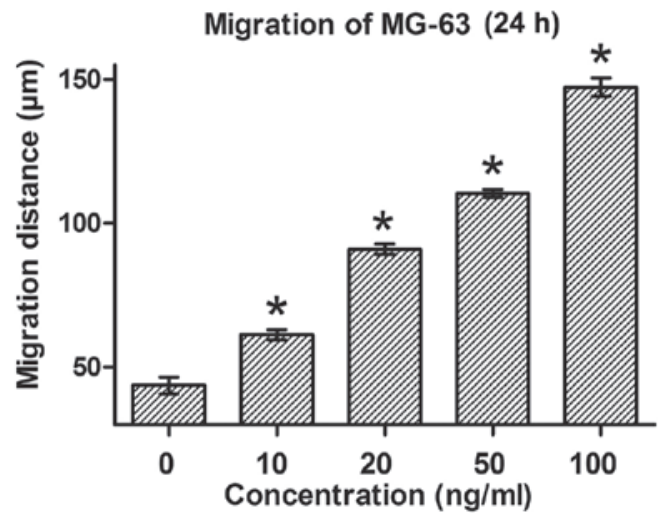

Figure 4. Effect of MGF-E peptide on MG-63 cell migration was analyzed by a wound-healing assay. MG-63 cells were seeded in 6-well plates for $24 \mathrm{~h}$, then wounds were created. Concomitantly, MG-63 cells were treated with MGF-E peptide at various concentrations $(0,10,20,50$ and $100 \mathrm{ng} / \mathrm{ml})$. Cell migration was observed $24 \mathrm{~h}$ after wounding. (A) Photographs display cells that had migrated into the wounded area, x100 magnification. (B) The migration distance in each group was calculated as (width at $0 \mathrm{~h}$ ) - (width at $24 \mathrm{~h}$ ). "P $<0.05$ vs. control. MGF-E, mechano-growth factor $\mathrm{E}$.

A

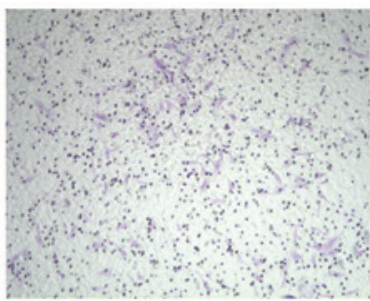

$\times 1000 \mathrm{ng} / \mathrm{ml}$

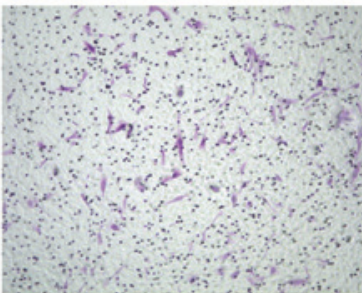

$\times 10010 \mathrm{ng} / \mathrm{ml}$

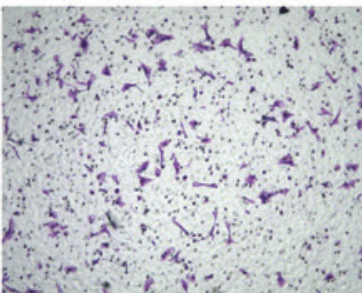
$\times 10020 \mathrm{ng} / \mathrm{ml}$

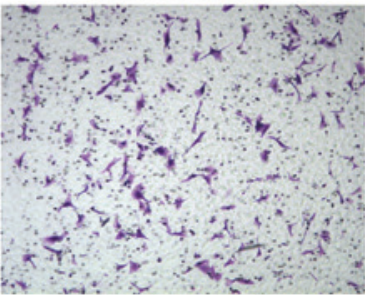
$\times 10050 \mathrm{ng} / \mathrm{ml}$

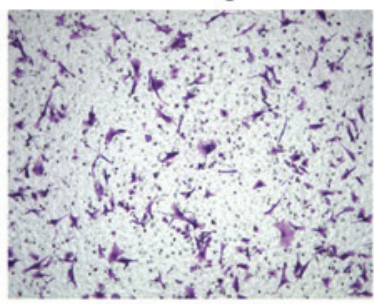
$\times 100100 \mathrm{ng} / \mathrm{ml}$
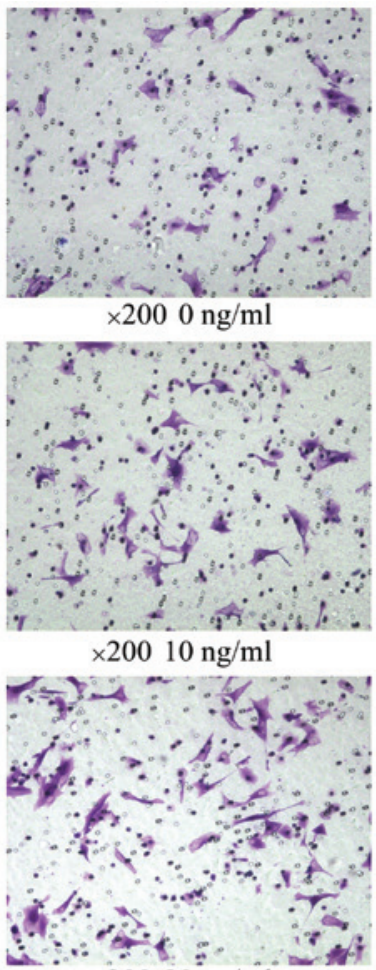
$\times 20020 \mathrm{ng} / \mathrm{ml}$

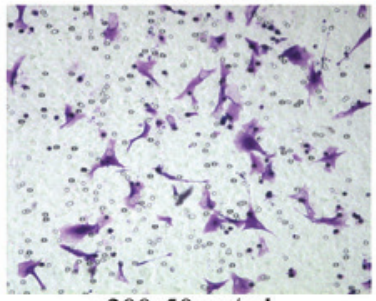
$\times 20050 \mathrm{ng} / \mathrm{ml}$

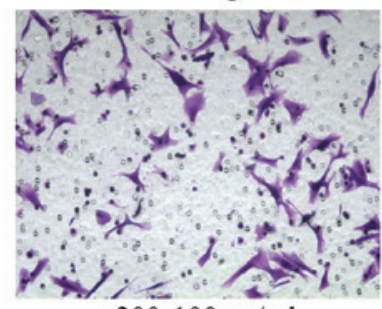

$\times 200100 \mathrm{ng} / \mathrm{ml}$

B

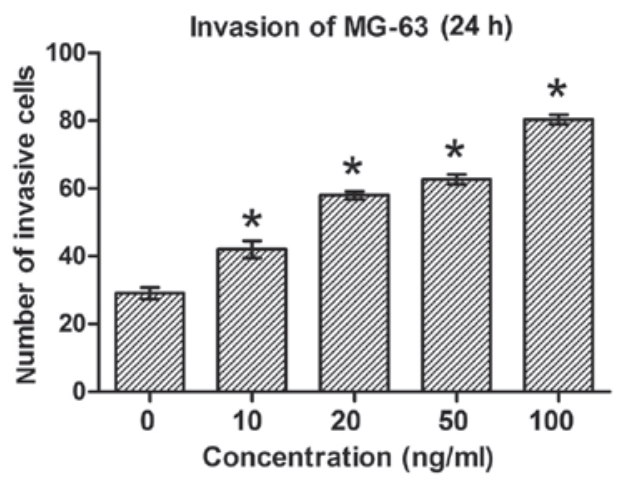

Figure 5. Effect of MGF-E peptide on the invasion of MG-63 cells. Invasion of MG-63 cells treated with MGF-E peptide at various concentrations $(0,10$, 20,50 and $100 \mathrm{ng} / \mathrm{ml}$ ) were analyzed at $24 \mathrm{~h}$ following the addition of MGF-E. (A) Photographs display cells that had travelled through the micropore membrane, with crytal violet staining, and (B) the histogram demonstrates the number of migrant cells. ${ }^{*} \mathrm{P}<0.05$ vs. control. MGF-E, mechano-growth factor E. 
Table I. Cell cycle phase and proliferation index of MG-63 cells exposed to MGF-E for $24 \mathrm{~h}$.

\begin{tabular}{|c|c|c|c|}
\hline \multirow[b]{2}{*}{ Sample } & \multicolumn{2}{|c|}{ Cell cycle phase (\% cells) } & \multirow[b]{2}{*}{ Proliferation index $(\%)$} \\
\hline & $\mathrm{G}_{1} / \mathrm{G}_{0}$ & $\mathrm{G}_{2} / \mathrm{M}+\mathrm{S}$ & \\
\hline Control & $81.605 \pm 2.934$ & $18.395 \pm 2.934$ & $18.395 \pm 2.934$ \\
\hline $10 \mathrm{ng} / \mathrm{ml}$ & $61.065 \pm 1.039^{\mathrm{a}}$ & $38.960 \pm 1.131^{\mathrm{a}}$ & $38.960 \pm 1.131^{\mathrm{a}}$ \\
\hline $20 \mathrm{ng} / \mathrm{ml}$ & $62.020 \pm 1.160^{\mathrm{a}}$ & $38.005 \pm 1.181^{\mathrm{a}}$ & $38.005 \pm 1.181^{\mathrm{a}}$ \\
\hline $50 \mathrm{ng} / \mathrm{ml}$ & $62.140 \pm 0.905^{\mathrm{a}}$ & $37.840 \pm 0.877^{\mathrm{a}}$ & $37.840 \pm 0.877^{\mathrm{a}}$ \\
\hline $100 \mathrm{ng} / \mathrm{ml}$ & $56.895 \pm 1.138^{\mathrm{a}}$ & $43.075 \pm 1.181^{\mathrm{a}}$ & $43.075 \pm 1.181^{\mathrm{a}}$ \\
\hline
\end{tabular}

Data are presented as the mean \pm standard deviation. ${ }^{a} \mathrm{P} \leq 0.05$ compared with the control. MGF-E, mechano-growth factor E.

A

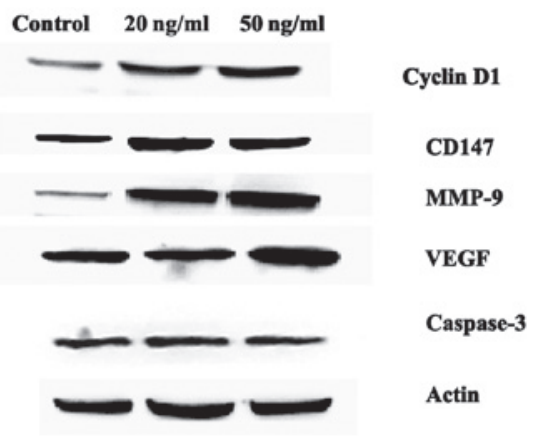

C

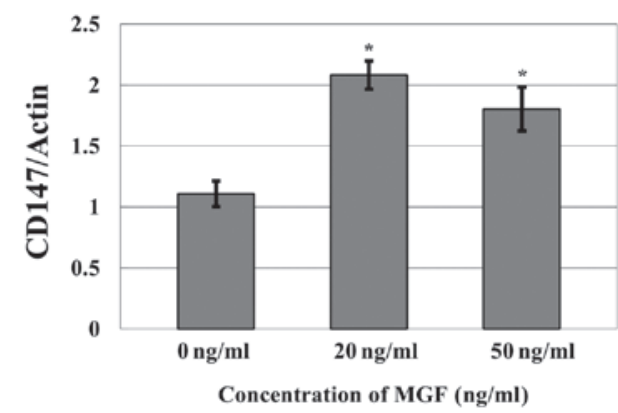

$\mathbf{E}$

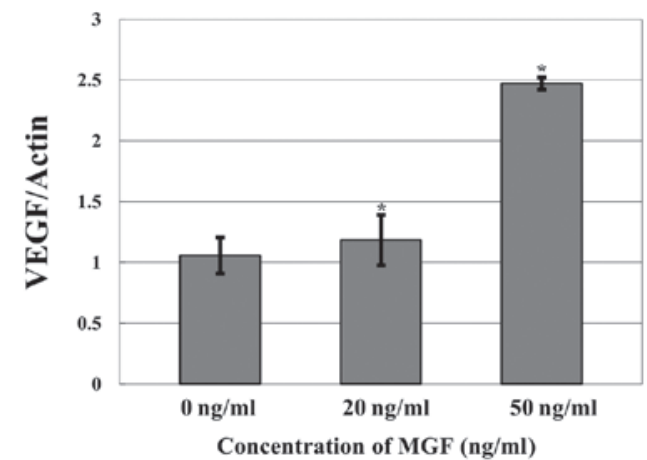

B

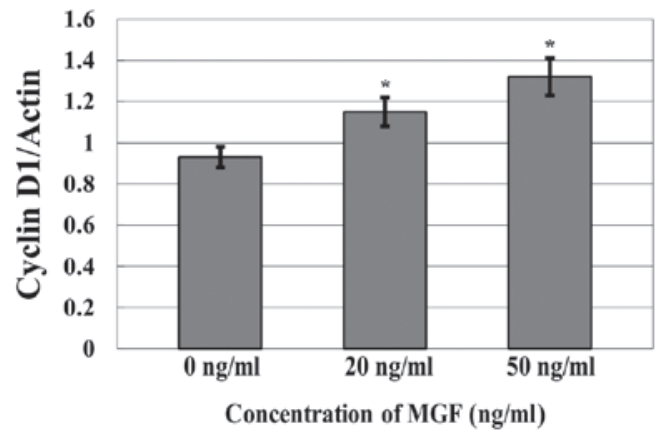

D

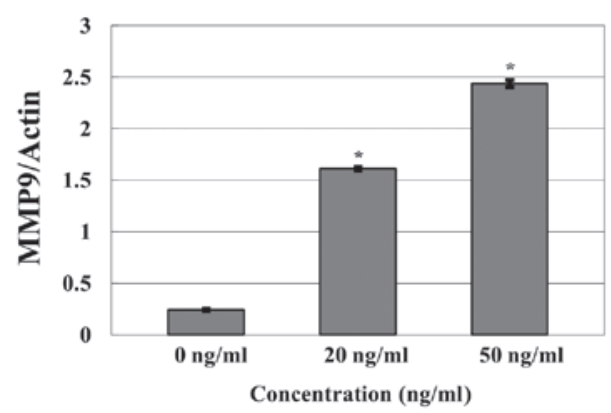

F

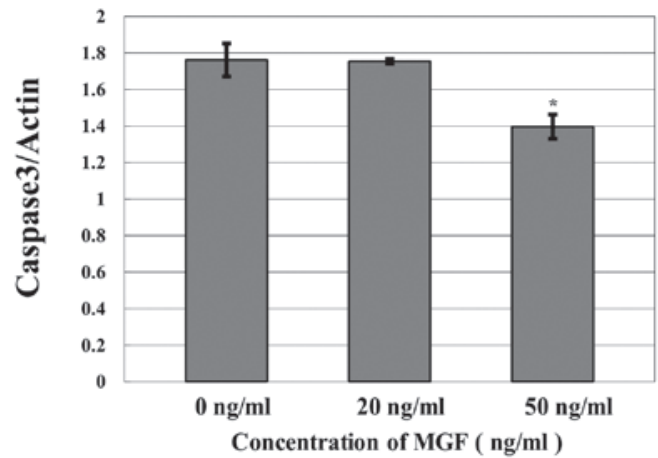

Figure 6. (A) Western blot demonstrating the effects of MGF-E on the expression of cyclin D1, CD147, MMP-9, VEGF and Caspase 3. Quantification of expression of (B) cyclin D1, (C) CD147, (D) MMP-9, (E) VEGF and (F) Caspase 3 in MG-63 cells exposed to MGF. "P<0.05, vs. control (0 ng/ml). MGF-E, mechano-growth factor E; MMP-9, matrix metalloproteinase 9; VEGF, vascular endothelial growth factor.

Statistical analysis. The results were analyzed using SPSS software, version 19.0 (IBM SPSS, Armonk, NY, USA). Student's t-test was conducted, and the results are presented as the mean \pm standard error. $\mathrm{P}<0.05$ was considered to indicate a statistically significant difference.

\section{Results}

Expression of MGF in the Hos, MHos and MG-63 cell lines. qPCR analysis demonstrated that MHos and MG-63 cells expressed MGF, while Hos cells did not (Fig. 1A). As presented in Fig. 1, MGF was differentially expressed in osteosarcoma cells. Normalization was conducted using GAPDH, and 


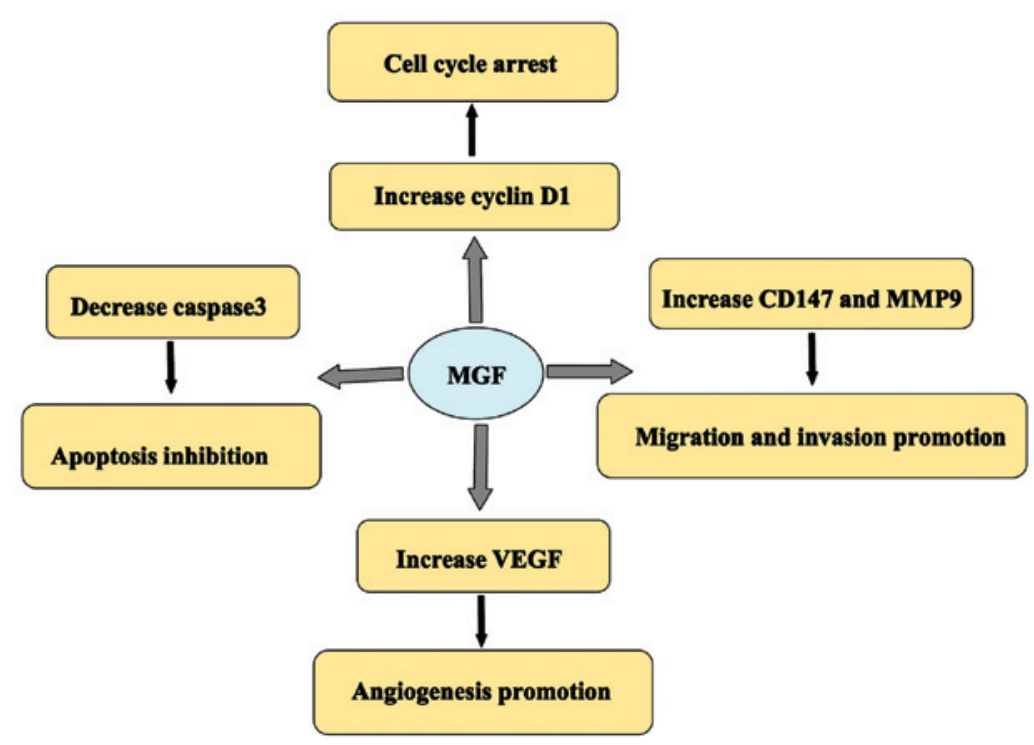

Figure 7. Proposed molecular mechanisms underlying the effects of MGF in osteosarcoma. MGF, mechano-growth factor; MMP-9, matrix metalloproteinase-9; VEGF, vascular endothelial growth factor.

its expression is presented in Fig. 1B. Furthermore, MGF expression was higher in MG-63 cells than that in MHos cells, indicating that the expression of MGF is associated with the degree of malignancy in osteosarcoma.

Effect of the MGF-E peptide on the proliferation capacity of MG-63 cells. Cell proliferation was evaluated in MG-63 cells treated with various concentrations of MGF-E peptide $(10,20$, 50 or $100 \mathrm{ng} / \mathrm{ml}$ ), as presented in Fig. 2. Following treatment for $48 \mathrm{~h}$, significant increases in the number of MG-63 cells were observed at all concentrations of MGF-E $\geq 10 \mathrm{ng} / \mathrm{ml}$ ( $\mathrm{P}<0.05$ compared with $0 \mathrm{ng} / \mathrm{ml}$; Fig. 2A). However, no effect on the proliferation of MG-63 cells was detected at $24 \mathrm{~h}$ (Fig. 2B). These results demonstrated that the MGF-E peptide may promote the proliferation of osteosarcoma cells.

Cell cycle distribution and proliferation index of $M G-63$ cells in response to $M G F-E$ peptide administration. In order to confirm whether the proliferation of MG-63 cells in response to MGF-E peptide was due to arrest at a certain cell cycle phase, flow cytometry and PI staining were used to detect DNA content and the proportion of cells in different phases of the cell cycle. MGF-E significantly altered cell cycle distribution in the cells, resulting in increased accumulation of cells in the $\mathrm{G}_{2} / \mathrm{M}+\mathrm{S}$ phases (from $18.395 \%$ in the control to $43.075 \%$ in the $100 \mathrm{ng} / \mathrm{ml}$ group; $\mathrm{P} \leq 0.05$; Table I). Each concentration of MGF used in the present study exerted an effect on cell cycle progression, compared with the control group. Cell proliferation activity was also indicated by the proliferation index (Fig. 3). Following treatment with MGF-E, proliferation index increased significantly compared with the control $(\mathrm{P}<0.05)$. These results demonstrated that the pro-proliferation effect of the MGF-E peptide is mediated via an effect on cell cycle progression in MG-63 cells.

Migration of MG-63 cells in response to the MGF-E peptide. In order to investigate the function of MGF in osteosarcoma cells, the migration of MG-63 cells in response to treatment with various concentrations of the MGF-E peptide $(0,10,20$, 50 or $100 \mathrm{ng} / \mathrm{ml}$ ) was observed. At $24 \mathrm{~h}$ after wounds were made, the migration distances of MG-63 cells were significantly increased in all MGF-E treatment groups compared with that in the control group $(\mathrm{P}<0.05$; Fig. 4$)$. Furthermore, with increasing concentrations of MGF-E, the effect was more marked. These results demonstrated that MGF-E effectively promoted the migration of MG-63 cells.

Invasion of MG-63 in response to the MGF-E peptide. Cell invasion was calculated from the number of cells observed to have passed through the $8-\mu \mathrm{m}$ pore of the polycarbonate membrane coated with collagen, which separated the upper and lower chambers. Crystal violet staining demonstrated that the number of MG-63 cells that crossed the basement membrane of the Transwell system was significantly increased in response to treatment with MGF-E $(\mathrm{P}<0.05$; Fig. 5). This effect occurred in a dose-dependent manner. This suggested that MGF is involved in inducing the invasion of MG-63 cells, and that this effect is associated with the concentration of the MGF-E peptide.

Effects of MGF on the expression of key proteins in $M G-63$ cells. Western blotting analysis demonstrated that the expression levels of cyclin D1, CD147, matrix metalloproteinase 9 (MMP-9) and vascular endothelial growth factor (VEGF) were all significantly increased in response to treatment with the MGF-E peptide (20 and $50 \mathrm{ng} / \mathrm{ml}$ ) compared with that in the control group $(0 \mathrm{ng} / \mathrm{ml})$. The expression of caspase 3 was significantly reduced in response to treatment with the MGF-E peptide (50 $\mathrm{ng} / \mathrm{ml}$ ) compared with that in the control group $(0 \mathrm{ng} / \mathrm{ml})$. These results suggested that increased MGF expression may upregulate cyclin D1, CD147 and MMP-9 expression, and suppress that of caspase 3. The effects of MGF-E on cell cycle distribution and proliferation in osteosarcoma cells may be due, at least in part, to the upregulation of cyclin D1 expression. Furthermore, MGF-E upregulated CD147 and MMP-9 expression, which 
may be responsible for the increased migration and invasion following treatment with MGF-E.

\section{Discussion}

IGF-I is one of the most abundant proteins in bone and is involved in the process of bone formation (26). In addition, IGFs are associated with the development of cancer and are involved in events required for metastasis, including the promotion of cell transformation, angiogenesis, proliferation and infiltration, and the inhibition of apoptosis $(27,28)$. MGF is an alternative splicing variant of IGF-I, which exerts similar effects to IGF-I in numerous respects, including satellite cell activation, aging and neuroprotection (29). However, there have been relatively few studies into the association between MGF expression and carcinogenesis.

Armakolas et al (16) intitally demosntrated that the IGF-I gene transcript, MGF, was specifically expressed in PC-3 and LNCaP prostate cancer cells. However, under the same experimental conditions, HPrEC normal human prostate epithelial cells did not express MGF isoforms. Subsequently, Philippou et al (17) demonstrated that MGF was expressed in MG-63 osteosarcoma cells. The present study also indicated that MGF was specifically expressed in malignant MG-63 and MHos cells. This may be an indication that the expression of MGF is associated with the degree of malignancy of osteosarcoma cells.

It has been documented that a synthetic MGF-E peptide, which comprises the final 24 amino acids of the translation product of the E domain of MGF, can stimulate the proliferation of prostate and osteosarcoma cancer cells $(16,17)$. The same proliferative effects of the MGF-E peptide were confirmed in the current study. To the best of our knowledge, this is the first study to interpret the effects of MGF on migration and invasion in cancer cells, in addition to examining the possible molecular mechanisms underlying its effects on the promotion of proliferation, migration and invasion.

The present results suggested that MGF significantly promotes the proliferation, migration and invasion of osteosarcoma cells. In addition, the promotion of proliferation by MGF was demonstrated to be a result of an increase in DNA synthesis and mitosis. During this process, the expression of cyclin D1 was increased after treatment with MGF-E for $48 \mathrm{~h}$, which indicated that cell cycle arrest may be due to the upregulation of cyclin D1 expression. The invasion and metastasis-associated molecular pathways which MGF may affect were also investigated. A previous study indicated that MMP-9 expression is closely associated with tumor cell invasion and metastasis (30). However, to the best of our knowledge, there have been no studies demonstrating that CD147 and MMP-9 are regulated by MGF. Therefore, the present study sought to determine the effects of MGF-E on CD147 and MMP-9 expression in MG-63 cells. The expression levels of CD147 and MMP-9 were significantly higher following treatment with MGF-E than that in the control cells. This suggests that MGF may promote MG-63 cell invasion by increasing the expression of CD147 and MMP-9.

The effects of MGF in osteosarcoma are hypothesized to act via a number of possible molecular mechanisms (Fig. 7). The upregulation of MGF in the current study led to cell cycle arrest.
Furthermore, cyclin D1 expression was increased in response to treatment with MGF. The results suggested that MGF may regulate progression through the cell cycle, by increasing the expression of cyclin D1, which is required for $G_{1} / S$ transition. CD147 and MMP-9 are involved in the invasion and metastasis of numerous types of human malignancy $(31,32)$. The present study demonstrated that MGF may promote the expression of CD147 and MMP-9, and that this may underlie the promotion of cell migration and invasion by MGF. Furthermore, MGF influenced apoptosis and angiogenesis in osteosarcoma cells by regulating the expression of caspase- 3 and VEGF.

The pathogenesis of cancer is a complicated process, in which different factors are involved at each stage. However, cancer cells share certain characteristics, including uncontrolled growth and the capacity to invade surrounding tissues or to metastasize to distant tissues. Therefore, the identification of universal biomarkers, independent of cancer-type is important.

\section{Acknowledgements}

This study was supported by a grant from the Natural Science Foundation of China (grant nos. 81271982 and 81071498).

\section{References}

1. Marulanda GA, Henderson ER, Johnson DA, Letson GD and Cheong D: Orthopedic surgery options for the treatment of primary osteosarcoma. Cancer Control 15: 13-20, 2008.

2. Vander Griend RA: Osteosarcoma and its variants. Orthop Clin North Am 27: 575-581, 1996.

3. Kim SY and Helman LJ: Strategies to explore new approaches in the investigation and treatment of osteosarcoma. Cancer Treat Res 152: 517-528, 2009.

4. Nardin A, Lefebvre ML, Labroquère K, Faure O and Abastado JP: Liposomal muramyl tripeptide phosphatidylethanolamine: Targeting and activating macrophages for adjuvant treatment of osteosarcoma. Curr Cancer Drug Targets 6: 123-133, 2006.

5. Xie XK, Yang DS, Ye ZM and Tao HM: Enhancement effect of adenovirus-mediated antisense $c$-myc and caffeine on the cytotoxicity of cisplatin in osteosarcoma cell lines. Chemotherapy 55: 433-440, 2009

6. Oosterhoff D, Witlox MA, van Beusechem VW, Haisma HJ, Schaap GR, Bras J, Kruyt FA, Molenaar B, Boven E, Wuisman PI, et al: Gene-directed enzyme prodrug therapy for osteosarcoma: Sensitization to CPT-11 in vitro and in vivo by adenoviral delivery of a gene encoding secreted carboxylesterase-2. Mol Cancer Ther 2: 765-771, 2003.

7. Shavlakadze T, Winn N, Rosenthal N and Grounds MD: Reconciling data from transgenic mice that overexpress IGF-I specifically in skeletal muscle. Growth Horm IGF Res 15: 4-18, 2005.

8. Yang S, Alnaqeeb M, Simpson H and Goldspink G: Cloning and characterization of an IGF-1 isoform expressed in skeletal muscle subjected to stretch. J Muscle Res Cell Motil 17: 487-495, 1996.

9. Goldspink G: Mechanical signals, IGF-I gene splicing, and muscle adaptation. Physiology (Bethesda) 20: 232-238, 2005.

10. Carro E, Trejo JL, Núñez A and Torres-Aleman I: Brain repair and neuroprotection by serum insulin-like growth factor I. Mol Neurobiol 27: 153-162, 2003.

11. Tang LL, Xian CY and Wang YL: The MGF expression of osteoblasts in response to mechanical overload. Arch Oral Biol 51: 1080-1085, 2006.

12. Mills P, Lafrenière JF, Benabdallah BF, El Fahime $M$ and Tremblay JP: A new pro-migratory activity on human myogenic precursor cells for a synthetic peptide within the E domain of the mechano growth factor. Exp Cell Res 313: 527-537, 2007.

13. Collins JM, Goldspink PH and Russell B: Migration and proliferation of human mesenchymal stem cells is stimulated by different regions of the mechano-growth factor prohormone. J Mol Cell Cardiol 49: 1042-1045, 2010. 
14. Matheny RW Jr, Nindl BC and Adamo ML: Minireview: Mechano-growth factor: A putative product of IGF-I gene expression involved in tissue repair and regeneration. Endocrinology 151: $865-875,2010$

15. Kuo YH and Chen TT: Novel activities of pro-IGF-I E peptides: Regulation of morphological differentiation and anchorage-independent growth in human neuroblastoma cells. Exp Cell Res 280: 75-89, 2002

16. Armakolas A, Philippou A, Panteleakou Z, Nezos A, Sourla A, Petraki $C$ and Koutsilieris M: Preferential expression of IGF-1Ec (MGF) transcript in cancerous tissues of human prostate: Evidence for a novel and autonomous growth factor activity of MGF E peptide in human prostate cancer cells. Prostate 70: 1233-1242, 2010.

17. Philippou A, Armakolas A, Panteleakou Z, Pissimissis N, Nezos A, Theos A, Kaparelou M, Armakolas N, Pneumaticos SG and Koutsilieris M: IGF1Ec expression in MG-63 human osteoblast-like osteosarcoma cells. Anticancer Res 31: 4259-4265, 2011.

18. Ates K, Yang SY, Orrell RW, Sinanan AC, Simons P, Solomon A, Beech S, Goldspink G and Lewis MP: The IGF-I splice variant MGF increases progenitor cells in ALS, dystrophic, and normal muscle. FEBS Lett 581: 2727-2732, 2007.

19. Quesada A, Micevych P and Handforth A: C-terminal mechano growth factor protects dopamine neurons: A novel peptide that induces heme oxygenase-1. Exp Neurol 220: 255-266, 2009.

20. Wang C, Li Z, Fu M, Bouras T and Pestell RG: Signal transduction mediated by cyclin D1: From mitogens to cell proliferation: A molecular target with therapeutic potential. Cancer Treat Res 119: 217-237, 2004.

21. Porter AG and Jänicke RU: Emerging roles of caspase-3 in apoptosis. Cell Death Differ 6: 99-104, 1999.

22. Harry LE and Paleolog EM: From the cradle to the clinic: VEGF in developmental, physiological, and pathological angiogenesis. Birth Defects Res C Embryo Today 69: 363-374, 2003.

23. Zhao S, Ma W, Zhang M, Tang D, Shi Q, Xu S, Zhang X, Liu Y, Song Y, Liu L and Zhang Q: High expression of CD147 and MMP-9 is correlated with poor prognosis of triple-negative breast cancer (TNBC) patients. Med Oncol 30: 335, 2013.
24. Gou X, Chen H, Jin F, Wu W, Li Y, Long J, Gong X, Luo M, Bi T, Li Z and He Q: Expressions of CD147, MMP-2 and MMP-9 in laryngeal carcinoma and its correlation with poor prognosis. Pathol Oncol Res 20: 475-481, 2014.

25. Daft PG, Yuan K, Warram JM, et al: Alpha-CaMKII plays a critical role in determining the aggressive behavior of human osteosarcoma. Mol Cancer Res 11: 349-359, 2013.

26. Crane JL and Cao X: Function of matrix IGF-1 in coupling bone resorption and formation. J Mol Med 92: 107-115, 2014.

27. Durai R, Davies M, Yang W, Yang SY, Seifalian A, Goldspink $\mathrm{G}$ and Winslet M: Biology of insulin-like growth factor binding protein- 4 and its role in cancer (review). Int $\mathrm{J}$ Oncol 28: 1317-1325, 2006.

28. van Golen CM, Schwab TS, Kim B, Soules ME, Su Oh S, Fung K, van Golen KL and Feldman EL: Insulin-like growth factor-I receptor expression regulates neuroblastoma metastasis to bone. Cancer Res 66: 6570-6578, 2006.

29. Matheny RW Jr, Nindl BC and Adamo ML: Minireview: Mechano-growth factor: A putative product of IGF-I gene expression involved in tissue repair and regeneration. Endocrinology 151: 865-875, 2010.

30. Tang ZY, Liu Y, Liu LX, Ding XY, Zhang H and Fang LQ: RNAi-mediated MMP-9 silencing inhibits mouse melanoma cell invasion and migration in vitro and in vivo. Cell Biol Int 37: 849-854, 2013.

31. Li Z, Ren Y, Wu QC, Lin SX, Liang YJ and Liang HZ: Macrophage migration inhibitory factor enhances neoplastic cell invasion by inducing the expression of matrix metalloproteinase 9 and interleukin-8 in nasopharyngeal carcinoma cell lines. Chin Med J (Engl) 117: 107-114, 2004.

32. Yu W, Liu J, Xiong X, Ai Y and Wang H: Expression of MMP9 and CD147 in invasive squamous cell carcinoma of the uterine cervix and their implication. Pathol Res Pract 205: 709-715, 2009. 